Article

\title{
High Diversity and Abundance of Foraminifera Associated with Mediterranean Benthic Red Algae Mats
}

\author{
Felix Ivo Rossbach *(D), Benedikt Merk (D) and Christian Wild (D)
}

Citation: Rossbach, F.I.; Merk, B. Wild, C. High Diversity and Abundance of Foraminifera Associated with Mediterranean Benthic Red Algae Mats. Diversity 2022, 14, 21. https://doi.org/ $10.3390 / \mathrm{d} 14010021$

Academic Editors: Michael Wink and Charalampos Dimitriadis

Received: 8 December 2021

Accepted: 20 December 2021

Published: 30 December 2021

Publisher's Note: MDPI stays neutral with regard to jurisdictional claims in published maps and institutional affiliations.

Copyright: (C) 2021 by the authors. Licensee MDPI, Basel, Switzerland. This article is an open access article distributed under the terms and conditions of the Creative Commons Attribution (CC BY) license (https:// creativecommons.org/licenses/by/ $4.0 /$ )

\author{
Marine Ecology Department, Faculty of Biology and Chemistry, University of Bremen, 28359 Bremen, Germany \\ bmerk@uni-bremen.de (B.M.); christian.wild@uni-bremen.de (C.W.) \\ * Correspondence: felix.rossbach@uni-bremen.de
}

\begin{abstract}
The Mediterranean Sea comprises habitats such as Posidonia oceanica seagrass meadows that exhibit high associated biodiversity of sessile organisms. Recent pilot research indicates that benthic mats formed by the scarcely investigated fleshy red alga Phyllophora crispa also host a high diversity of benthic fauna. Among the key taxa found in these mats in the recent pilot studies are benthic foraminifera that live as epiphytes on the red algae thalli. Knowledge about their abundance and species richness associated with this habitat in relation to reference habitats is missing. We thus carried out a comparative assessment focusing on foraminifera within samples from P. crispa mats and neighboring P. oceanica meadows on five different sampling sites around Giglio Island in the Tuscan Archipelago (Tyrrhenian Sea, Italy). A total of 104 different foraminiferal taxa were identified, of which a total of 85 taxa were found in P. crispa samples (46 exclusively in this habitat). This biodiversity was higher compared to other studies on phytal habitats in the Mediterranean Sea. The number of foraminiferal taxa associated with $P$. crispa was significantly higher (average $27.5 \pm 8.1$ taxa) compared to $P$. oceanica (leaves average $7.0 \pm 3.6$, shoots average $7.9 \pm 3.4$ taxa). The abundance of foraminifera (12,000 individuals $\mathrm{m}^{-2}$ surface area of $P$. crispa mat) was also higher than in the neighboring P. oceanica meadows (7792 individuals $\mathrm{m}^{-2}$ leaf and 8171 individuals $\mathrm{m}^{-2}$ shoot surface area). The most frequently found taxa across habitats were Miniacina miniacea, Lobatula lobatula, and Sejunctella sp. (24\%, 20\%, and $6 \%$ of the total population, respectively). Our results imply that $P$. crispa mats host an exceptional diversity of associated foraminifera that is even higher than those associated with seagrass meadows. Red algae mats built by P. crispa may thus be considered as potential refuge habitats and biodiversity reservoirs in management and conservation.
\end{abstract}

Keywords: Phyllophora crispa; phytal habitat; hard-bottom communities; ecosystem engineer; Mediterranean Sea; epibionts

\section{Introduction}

The Mediterranean Sea harbors almost 17,000 described eukaryotic species [1], a high amount of biodiversity that is accompanied by a high rate of endemism (estimated $20 \%$ ) resulting from its somewhat enclosed geographical position [2]. Together with this high rate of endemism, this high biodiversity marks the region as a "biodiversity hotspot" $[1,3,4]$. On a smaller scale, the structural complexity of many Mediterranean habitats (e.g., Posidonia oceanica seagrass meadows) facilitates their role as biodiversity hotspots by providing spawning grounds, nurseries, and permanent settling space for a variety of sessile and mobile species across habitat borders [5-9]. The ecological niches required for this high biodiversity are often created by spatial or temporal gradients (e.g., light and temperature, as recently described for P. crispa mats [10]) formed by an engineering species [11]. Engineering species may alter their environment by their growth, while others actively change local conditions to favor inhabiting species. The resulting modification of the habitat may result in shifts of ecological zonation (e.g., algae accumulating debris as a food source for detritivores) by mitigating stressors for depending species [12]. Often, the 
inhabitant also mitigates stress for the engineer, e.g., by fending off predators or cleaning out competitors [13,14].

Well-known habitats of high diversity in the Mediterranean Sea are Posidonia oceanica (L.) Delile, 1813 meadows, and coralligenous habitats. The seagrass species P. oceanica is a refuge for exceptional biodiversity and holds commercial value, e.g., by providing nursery grounds for important fish species [15]. The structural complexity of the meadow facilitates diverse communities of sessile invertebrates by providing secondary settling grounds and enhancing the settlement of planktonic life stages $[5,16]$. The calciferous bioconstructions of coralligenous habitats are mainly built by encrusting red algae and secondarily by calcifying invertebrate species, building a structurally complex matrix, and providing biogenic substrate for a wide range of associated biota [7]. Both are thus habitat-forming species and can be considered ecosystem engineers.

Recently, the mats of the red macroalgae Phyllophora crispa (Hudson) P.S.Dixon, 1964 have gained some attention as engineering species and potential hotspots of sessile epifauna biodiversity in the Mediterranean Sea [17-22]. In the Black Sea, these habitats facilitate prosperous communities and have led to establishing a marine reserve in the Bay of Odesa [23]. In the Mediterranean Sea, assemblages of different macroalgae have been shown to host diverse epiphytic foraminiferal communities [24,25].

In the Mediterranean Sea, dense mats of $P$. crispa have been reported to form hardbottom communities in the Tyrrhenian Sea, around the islands Giglio $[19,20]$ and Sardina $[17,18]$. However, only a few studies describe the associated biodiversity in these mats, even though the composition of associated biodiversity differs between classical hotspots (i.e., P. oceanica meadows) and sciaphilic (shade-loving) hardbottom communities [26,27].

Foraminifera are unicelled protists with a high taxonomic diversity and cosmopolitan distribution across all marine ecosystems, brackish, and rarely freshwater habitats [28,29]. Foraminifera inhabit pelagic and benthic environments; the latter may be colonized by recent offspring or settlement of pelagic propagules [30]. In particular, vegetated bottoms form suitable habitats for epiphytic foraminifera, and primarily seagrass meadows have been studied for their foraminiferal assemblages [31-37]. Some studies have also shown the importance of macro-algae as particular habitat for epiphytic foraminifera $[38,39]$. Many taxa of foraminifera host different symbionts, such as red-/green algae, diatoms, or dinoflagellates [40]. Long-lived, symbiont-bearing benthic species larger than $3 \mathrm{~mm}^{3}$ are summarized as larger benthic Foraminifera (LBF) [41,42]. In particular, LBF species are important calcifiers [43] and have been recognized as essential indicators for water quality and healthiness of marine ecosystems [44-46]. Key features for this function are their relatively short lifespan and reproductive cycle compared to benthic epifauna, their ubiquity, and sensitivity to biotic and abiotic perturbations, leading to rapid community composition changes after environmental disturbances [47-49]. The distribution patterns and role of foraminiferal communities in Mediterranean P. crispa mats are relatively unstudied to date. With this work, we aim to answer the following research questions:

1. What is the abundance and diversity of epiphytic foraminifera in P. crispa mats in relation to P. oceanica meadows?

2. What is the composition of epiphytic foraminifera morphotypes in P. crispa mats?

To answer these questions, we conducted a comparative field study of $P$. crispa mats and P. oceanica meadows along the coast of Giglio Island in the Tuscan Archipelago (northwestern Mediterranean Sea). We assessed the quantity of foraminifera occurrence and species composition at five different sampling sites.

\section{Materials and Methods}

\subsection{Sampling Activities}

The study area is located along the northeastern and northwestern coasts of Giglio Island, in the Tuscan Archipelago National Park (42 $21^{\prime} 19.4^{\prime \prime} \mathrm{N} 10^{\circ} 54^{\prime} 06.1^{\prime \prime} \mathrm{E}$, Tyrrhenian Sea) (Figure 1). Granite slopes characterize the benthic infralittoral around the island, alternating with sand bottoms, where P. oceanica meadows, P. crispa mats, and coralligenous 
habitats colonize the sea bed. Five sampling sites were chosen where P. crispa mats and $P$. oceanica meadows occur at similar target water depths. SCUBA divers conducted sampling at a water depth of $30 \mathrm{~m}$, where previous observations confirmed dense occurrences of $P$. crispa. Samples of $P$. oceanica were taken randomly between 20 and $30 \mathrm{~m}$ depth, a few meters above the lower boundary, to avoid bias by sampling at the ecological limit of the plant. The sampling sites included three locations with P. crispa mats (Site PC1, 2, and 3; Figure 1), two with only P. oceanica meadows (Site PO and 6), and another site (Site mix) with both habitats being present. Sampling activities took place on a timely randomized schedule between May and July 2019. Mats of dense P. crispa stands with a minimum thickness of five $\mathrm{cm}$ were chosen randomly. A handful of whole algae was carefully removed with the holdfast from the rock surface using a spatula. Each site was sampled four times, resulting in 16 P. crispa mat samples. All sampling was done with a spatula or scissors to avoid dropping of the specimen due to shaking movements (e.g., by just ripping off material) before immediately transferring the material into a sampling jar as described in previous studies $[24,33]$. We decided for this method to focus on the living, epiphytic foraminifera and avoid loss of fragile taxa by drying or sieving methods.

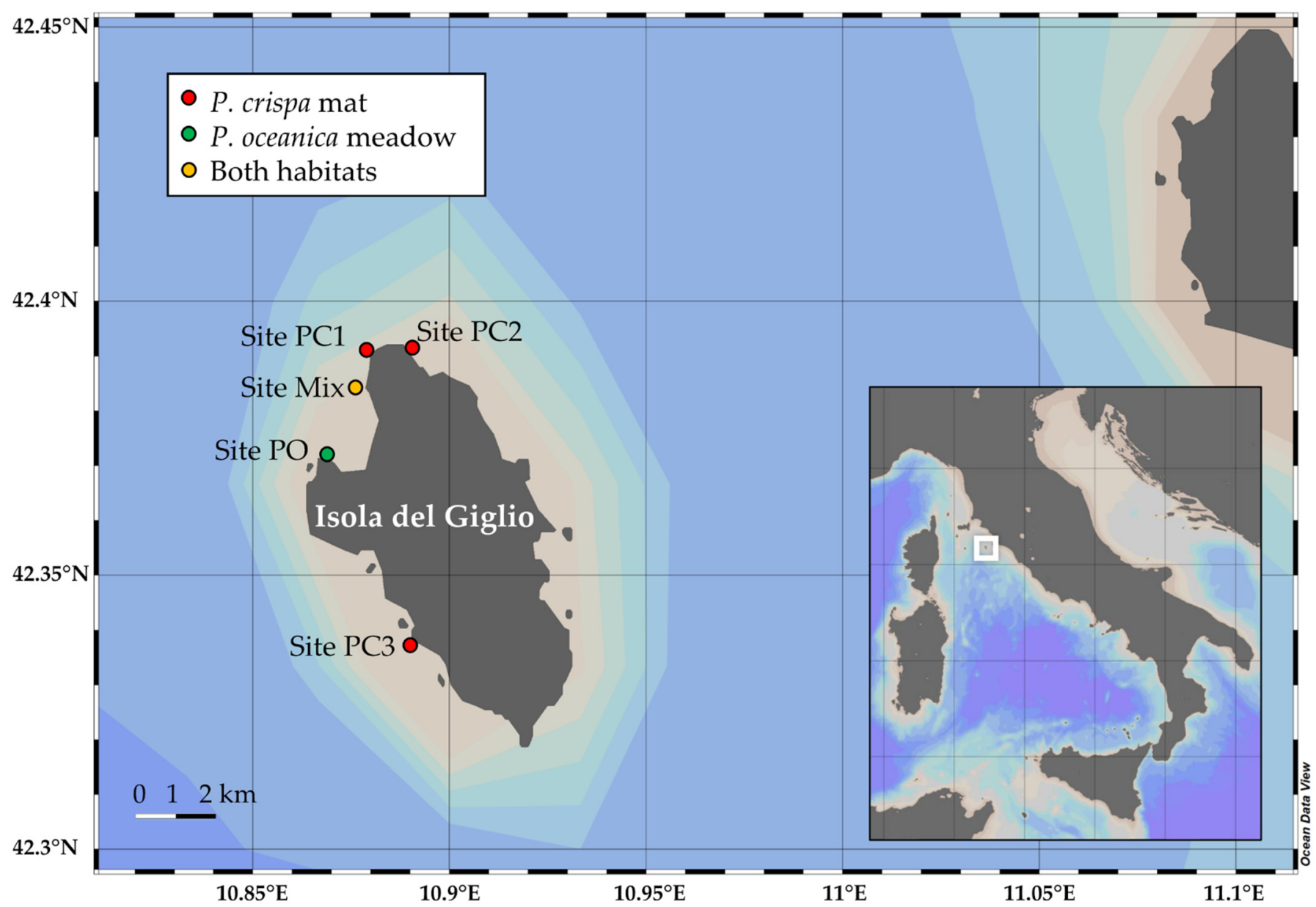

Figure 1. Location of the study area in the Tyrrhenian Sea with sampling sites around Giglio Island marked in red for Phyllophora crispa mats, green for Posidonia oceanica meadows, and yellow where both habitats were sampled, made with OceanDataView [50].

In total, 20 P. oceanica shoots and 18 leaves (site PO: 10 shoots and 9 leaves; Site Mix: 10 shoots and 9 leaves) were sampled at the respective sites. Shoots were cut at the lowest point to the rhizome node, and leaves were cut off at the sheath. All samples were transferred into one-liter PVC containers, allowing enough water inside to keep a constant temperature and sufficient oxygen supply for the biota (approximately $1 / 3$ sample material 
and $2 / 3$ seawater). After each dive, samples were directly transferred into husbandry basins at the Institute for Marine Biology (IfMB, Campese, Italy) and kept at constant temperature $\left(18{ }^{\circ} \mathrm{C}\right.$, equivalent to in situ temperature), with bubbling stones for oxygen supply. Processing of samples took place within three days after sampling. Shoots and leaves were treated separately because they are widely recognized as two sub-habitats with different ecological traits [51,52]. The sample completeness was confirmed with the rarefaction and interpolation method described by Chao et al. (Appendix A Figure A1) [53]. We also opted for this sampling approach to examine a similar surface area for each habitat and site (see results section).

In addition to the biodiversity assessments, we measured daily cycles of environmental parameters (i.e., oxygen and $\mathrm{pH})$ on site $\mathrm{PC} 2$, where P. oceanica meadow $(n=12)$, P. crispa mat $(n=22)$, and bare rock bottom $(n=12)$ were found in close vicinity $(<10 \mathrm{~m}$ distance). Oxygen concentration $(\mathrm{mg} / \mathrm{L})$ and $\mathrm{pH}$ were measured at the bottom of each habitat using Eureka Manta loggers (GEO Scientific Ltd.), set to one-minute measuring intervals. The obtained data were plotted as average values per hour \pm SD.

\subsection{Species Identification}

All samples were examined as a whole in water bowls containing seawater under stereo magnifiers (maximum $45 \times$ magnification) or microscope (maximum $400 \times$ magnification) as needed. The leaves of $P$. oceanica were cut into pieces of $8 \mathrm{~cm}$ for easier handling under the stereomicroscope and to avoid double-counting. The shoots were analyzed as a whole. Algae thalli of P. crispa were carefully separated into single phylloids for the analysis. This study focused on living epiphytic foraminifera $>300 \mu \mathrm{m}$ to avoid juveniles and abundance bias due to short-lived, opportunistic species.

All foraminiferal specimens found in the samples were counted and identified to the lowest possible taxonomic level using relevant identification literature $[32,36,54,55]$ and online resources (marinespecies.org, mindat.org, accessed on 16 June 2021) as a cross-reference. Species were then further categorized into morphotypes regarding their ecological features. We followed the categories proposed by Mateu-Vicens et al. in adaptation for the Mediterranean Sea, based on the original concept of Langer [35,37]. In this adaptation, five morphotypes were used: $\mathrm{A}^{*}$ and $\mathrm{SB}$ for long-lived (lifespan of 1 year or more) and sensitive species, where $\mathrm{A}^{*}$ are mostly flat and encrusting forms and SB species bear symbionts (e.g., Miniacina spp. and Peneroplis spp., respectively). Opportunistic species with an upright aperture were categorized as $\mathrm{D}^{*}$ (e.g., Textularia spp). Small, heterotrophic species were categorized as B or C, where B comprises species with wide apertures and pseudopodal networks, and B encompasses species with multiple apertural openings, attached to the substrate via pseudopods.

Numbers of foraminifera were then related to the surface area of the substrate (P. crispa, respectively $P$. oceanica material as subsequently described). For $P$. crispa samples, all algae material was placed on top of laminated millimeter paper in a dissection dish with seawater and flattened with an acrylic glass pane. Using a tripod, pictures were taken from the top at a constant $90^{\circ}$ angle. The surface area of the algae material was then calculated with ImageJ (version 1.52o) and multiplied by two to account for both sides of the phylloids. To calculate the P. oceanica shoot surface, a cylindrical shape was assumed and calculated after measuring the length and diameter of each sample. The straight leaves of $P$. oceanica were measured for length and width to calculate the surface area. This area was then doubled to account for both sides of each leaf.

\subsection{Diversity Descriptors}

The diversity of the epiphytic foraminiferal community was assessed with five descriptors: The total number of taxa per site and habitat, the Shannon diversity index (Appendix A Formula (A1)) [56], the Pielou index for evenness (Appendix A Formula (A2)) [57], plus the FORAM index and the lifespan index [35,37]. Additionally, we assessed the total density of individual foraminifera per $\mathrm{m}^{2}$ of seafloor. We calculated the FORAM index [46] and 
the lifespan index, as previously described for the Mediterranean Sea [35], based on the aforementioned morphotype categories. The FORAM index considers the proportions of small, heterotrophic taxa, larger, symbiont-bearing taxa, and stress-tolerant taxa. The index increases with higher abundances of symbiont-bearing taxa, and decreases with higher abundances of stress-tolerant taxa. The lifespan index emphasizes differences in the foraminiferal community regarding opportunistic vs. persistent taxa dominance-with lower values for high abundances of opportunistic taxa $\left(D^{*}\right)$, and higher values for longer living forms $\left(\mathrm{A}^{*}\right.$ and $\left.\mathrm{SB}\right)$. A detailed figure of the morphotype classification and explanation of the calculations can be found in the original publication [35].

All results were plotted as boxplots and reported as means per site with the respective standard error.

To further analyze the functional composition of the community, all found taxa were pooled according to their test material, and the relative composition of each site was plotted.

\subsection{Statistical Analysis}

Differences in the structure of foraminiferal communities among sites and habitats were tested using multivariate permutational ANOVA (PERMANOVA) [58]. Differences in the diversity descriptors among sites and habitats at the site mix were tested using pairwise Wilcoxon-Mann-Whitney tests. Data were not transformed in order to minimize potential bias. The Foraminiferal assemblages were hierarchically clustered with Spearman ranked correlation (average linkage) using the software 'heatmapper' [59] to reveal differences in the taxonomic (Families) and ecological (test material) composition among sites and visually highlight variances in the assemblages among habitats. Analyses and boxplots were made with $R$ (version 4.0.2) [60].

\section{Results}

\subsection{Daily Cycles of Water Parameters}

Our measurements showed higher $\mathrm{pH}$ values inside the P. crispa mat (average $8.36 \pm 0.01$ ) than inside the P. oceanica meadow (average $8.21 \pm 0.01$ ) and on a hardbottom reference habitat (average $8.32 \pm 0.02$; Figure 2A). Inside the P. crispa mat, the values fluctuated more ( 0.11 units) compared to $P$. oceanica meadow ( 0.05 units) and hardbottom (0.08 units).

The measured oxygen concentrations showed similar patterns for the P. crispa mat and hardbottom habitat (average $8.17 \pm 0.10 \mathrm{mg} \mathrm{L}^{-1}$, and average $8.20 \pm 0.07 \mathrm{mg} \mathrm{L}^{-1}$, respectively), compared to the P. oceanica meadow (average $7.90 \pm 0.14 \mathrm{mg} \mathrm{L}^{-1}$; Figure 2B). Here, the variation was highest inside the $P$. oceanica meadow $\left(0.47 \mathrm{mg} \mathrm{L}^{-1}\right)$ compared to the P. crispa mat $\left(0.33 \mathrm{mg} \mathrm{L}^{-1}\right)$ and the hardbottom habitat $\left(0.24 \mathrm{mg} \mathrm{L}^{-1}\right)$.

\subsection{Diversity of the Foraminiferal Community}

We examined a total surface of $0.215 \mathrm{~m}^{2}$ of $P$. crispa material (average $0.054 \mathrm{~m}^{2}$ per site). The examined surface of P. oceanica was $0.086 \mathrm{~m}^{2}$ of shoots (average $0.043 \mathrm{~m}^{2}$ per site) and $0.054 \mathrm{~m}^{2}$ of leaves (average $0.053 \mathrm{~m}^{2}$ per site). A total of 3.639 foraminiferal specimens were counted, and 104 taxa were examined, out of which 81 were found on P. crispa phylloids (46 exclusively on P. crispa). While the abundance of single taxa showed no significant differences among $P$. crispa sites, the communities differed significantly among $P$. oceanica sites and sub-habitats (shoots and leaves, Table 1). We thus consolidated the data of P. crispa mats for further assessment of differences in the diversity among the different habitats (Figure 3). 

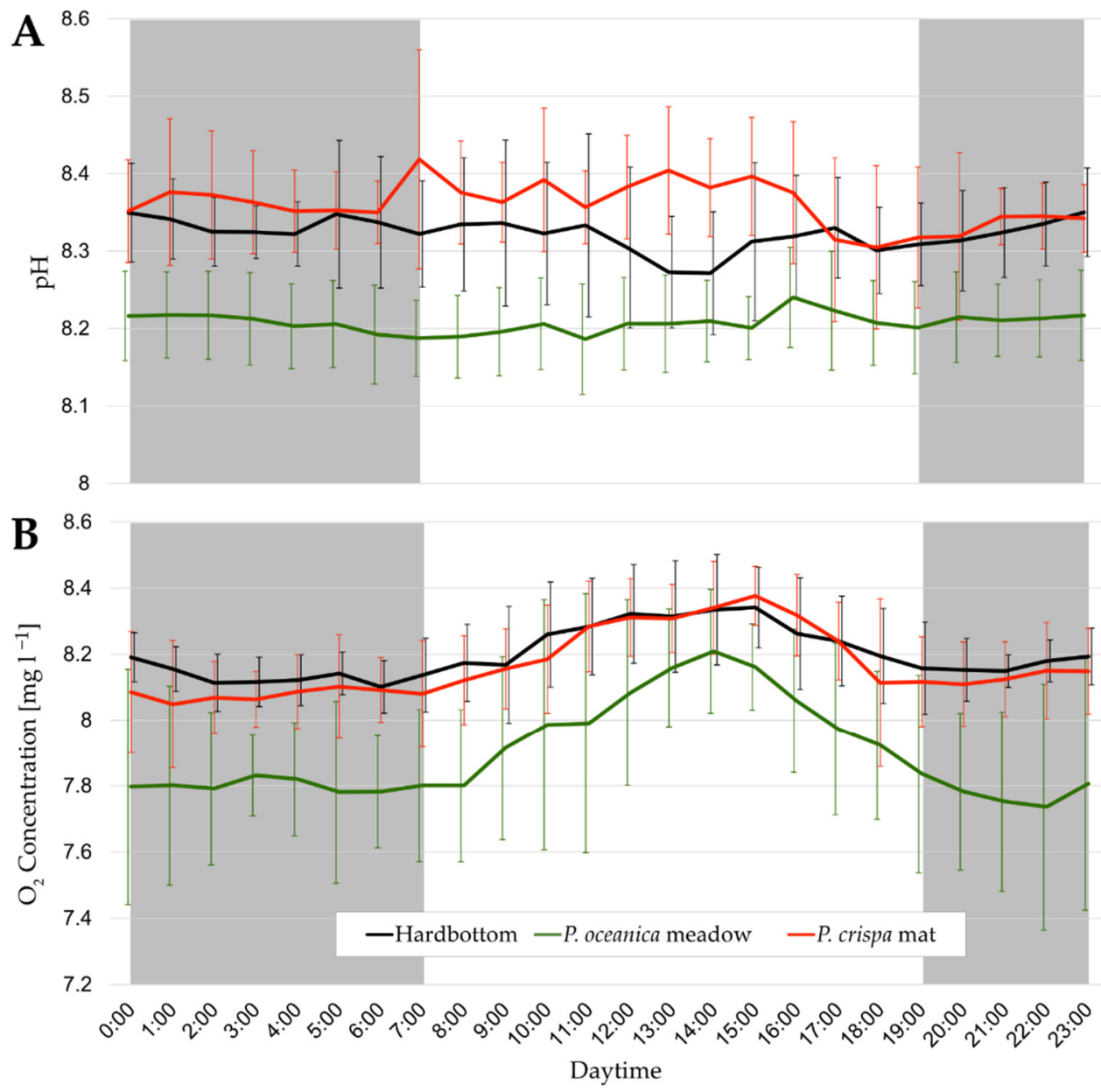

Figure 2. Daily cycles of water parameters measured on Site PC2 in Phyllophora crispa mat (red), Posidonia oceanica meadow (green), and bare rock bottom as reference (black). (A) pH and (B) oxygen concentration $\left(\mathrm{mg} \mathrm{L}^{-1}\right)$, measured at the bottom of the respective habitat. Error bars indicate standard deviation, grey areas indicate dark phases.

Table 1. Results of permutational ANOVA tests for differences among sites and habitats. Posidonia oceanica sub-habitats resemble leaves and shoots. Significant results $(p>0.05)$ are indicated in bold.

\begin{tabular}{|c|c|c|c|c|c|}
\hline \multicolumn{6}{|c|}{ Foraminiferal Assemblages of $P$. crispa Mats } \\
\hline Source & Df & SS & $\mathbf{R} 2$ & $\mathbf{F}$ & $p$ \\
\hline site & 3 & 0.3898 & 0.2161 & 1.1028 & 0.313 \\
\hline residual & 12 & 1.4138 & 0.7839 & & \\
\hline total & 15 & 1.8036 & 1.0000 & & \\
\hline \multicolumn{6}{|c|}{ Foraminiferal Assemblages of $P$. oceanica Meadows } \\
\hline Source & Df & SS & R2 & $\mathbf{F}$ & $p$ \\
\hline sub-habitat & 1 & 4.5640 & 0.3886 & 25.7381 & 0.001 \\
\hline site & 1 & 0.6696 & 0.0570 & 3.7759 & 0.006 \\
\hline sub-habitat:site & 1 & 0.4833 & 0.0411 & 2.7252 & 0.024 \\
\hline residual & 34 & 6.0291 & 0.5133 & & \\
\hline total & 37 & 11.7459 & 1.0000 & & \\
\hline
\end{tabular}




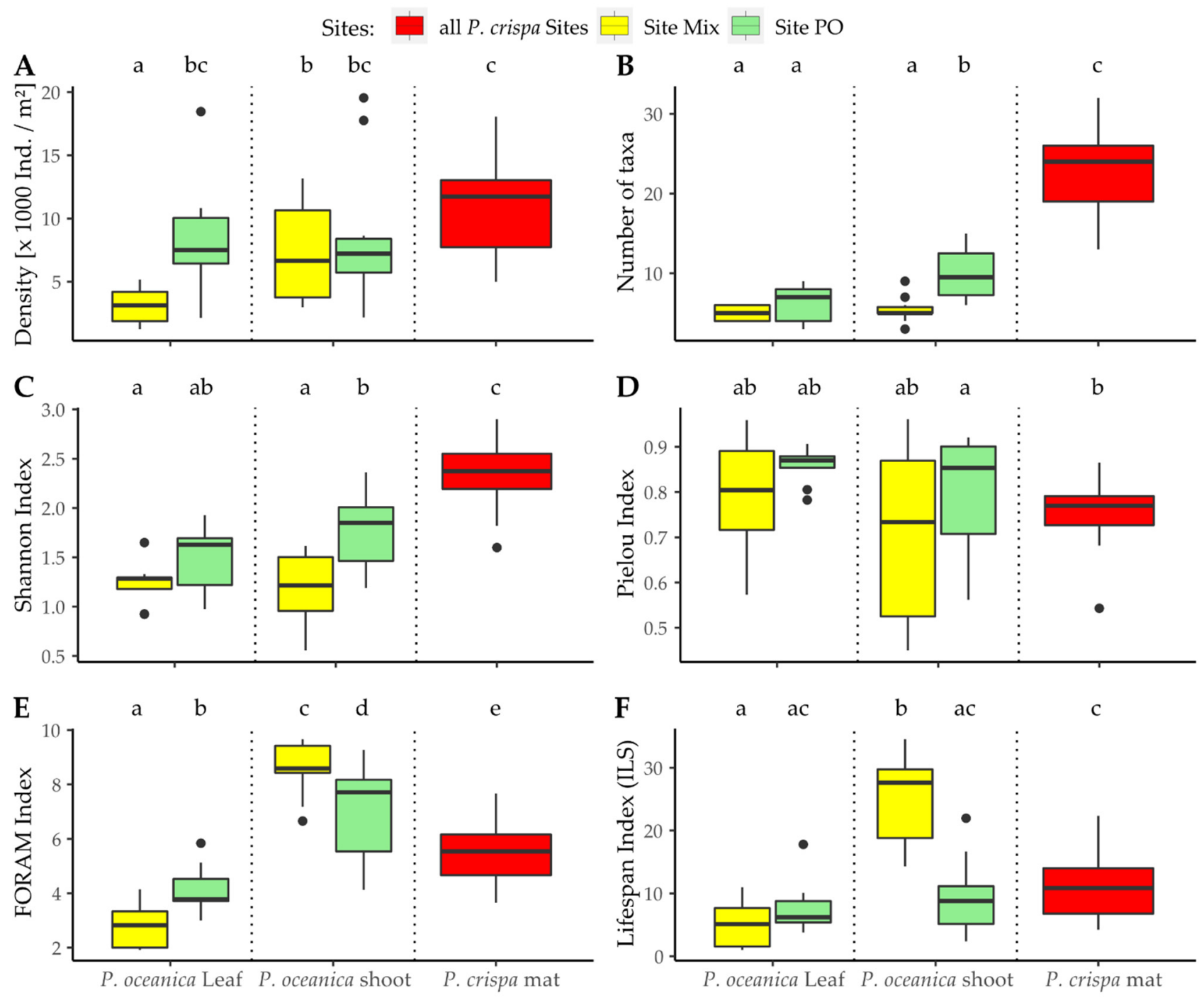

Figure 3. Abundance and diversity of foraminifera in P. crispa mats and P. oceanica meadows. (A) mean densities of foraminifera per $\mathrm{m}^{2}$ substrate per site, (B) total numbers of identified taxa, (C) Shannon diversity indices, (D) Pielou evenness indices, (E) FORAM indices, and (F) lifespan indices reported for the investigated Phyllophora crispa sites in comparison to Posidonia oceanica shoots and leaves. Compact letter displays show significance levels resulting from Wilcoxon-Mann-Whitney pairwise comparison, boxes with different letters differed significantly $(p<0.05)$. Black dots resemble outliers.

The most frequently found species across all samples was Miniacina miniacea (average $2081 \pm 2848$ individuals $\mathrm{m}^{-2}$ surface area), which was most abundant on the shoots (average $4117 \pm 3602$ individuals $\mathrm{m}^{-2}$ surface area; Table 2) and P. crispa mats (average $1877 \pm 1366$ individuals $\mathrm{m}^{-2}$ surface area), but not found on $P$. oceanica leaves. The most frequent species on both leaves (average $2128 \pm 1783$ individuals $\mathrm{m}^{-2}$ surface area) and P. crispa (average $3147 \pm 1590$ individuals $\mathrm{m}^{-2}$ surface area) was Lobatula lobatula. Both species develop calcareous perforate tests and resemble some of the larger species of Foriminiferans in this study. While M. miniacea and L. lobatula show the highest values across all P. crispa sites, site PC2 also showed a high amount of Sejunctella sp. (average $1100 \pm 303$ individuals $\mathrm{m}^{-2}$ surface area). Total LBF (Peneroplis spp., Sorites sp. and Vertebralina sp.; Table 2) counts and diversity were highest in P. crispa samples ( 3 species, average $183 \pm 239$ individuals $\mathrm{m}^{-2}$ surface area) compared to $P$. oceanica shoots ( 2 species, average $119 \pm 143$ individuals $\mathrm{m}^{-2}$ surface area) and P. oceanica leaves (1 species, average $37 \pm 123$ individuals $\mathrm{m}^{-2}$ surface area). One LBF species (Peneroplis planatus) was only found on P. crispa. 
Table 2. The five most abundant species per habitat (top) and average abundance of LBF species (bottom). Numbers are average abundance per $\mathrm{m}^{2}$ substrate (AVG) \pm standard deviation (STDEV); the most abundant species per habitat are indicated in bold. ${ }^{1}$ according to Mateu-Vicens et al. and Langer $[35,37]$. No LBF were among the most abundant species.

\begin{tabular}{|c|c|c|c|c|c|c|c|c|c|}
\hline & \multirow{2}{*}{ Family } & \multirow{2}{*}{ Species } & \multirow{2}{*}{ Ecotype $^{1}$} & \multicolumn{2}{|c|}{ P. crispa Mats } & \multicolumn{2}{|c|}{ P. oceanica Leaves } & \multicolumn{2}{|c|}{ P. oceanica Shoots } \\
\hline & & & & AVG & STDEV & AVG & STDEV & AVG & STDEV \\
\hline \multirow{10}{*}{ 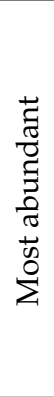 } & Cibicididae & Lobatula lobatula & B & 3147 & 1590 & 2127 & 1783 & 129 & 218 \\
\hline & Homotrematidae & Miniacina miniacea & $A^{*}$ & 1877 & 1366 & 0 & 0 & 4117 & 3602 \\
\hline & Hauerinidae & Unknown & $A^{*}$ & 1245 & 855 & 716 & 1330 & 0 & 0 \\
\hline & Discorbinellidae & Discorbinella bertheloti & $\mathrm{B}$ & 472 & 338 & 931 & 1076 & 249 & 362 \\
\hline & Spirillinidae & Sejunctella sp. & $\mathrm{A}^{*}$ & 465 & 505 & 15 & 62 & 912 & 899 \\
\hline & Planorbulinida & Planorbulina mediterranensis & $A^{*}$ & 365 & 266 & 353 & 484 & 132 & 252 \\
\hline & Hauerinidae & Miliolinella subrotunda & $D^{*}$ & 169 & 285 & 25 & 67 & 360 & 506 \\
\hline & Hauerinidae & Quinqueloculina seminula & $\mathrm{D}^{*}$ & 163 & 201 & 0 & 0 & 281 & 388 \\
\hline & Ammoniidae & Ammonia beccari & $\mathrm{B}$ & 86 & 275 & 723 & 605 & 119 & 248 \\
\hline & Trochamminidae & Lepidodeuterammina ochracea & $A^{*}$ & 71 & 161 & 28 & 82 & 357 & 580 \\
\hline \multirow{4}{*}{ 峉 } & Peneroplidae & Peneroplis pertusus & SB & 153 & 239 & 0 & 0 & 66 & 143 \\
\hline & Peneroplidae & Peneroplis planatus & SB & 17 & 37 & 0 & 0 & 0 & 0 \\
\hline & Soritidae & Sorites orbiculus & SB & 13 & 41 & 37 & 123 & 0 & 0 \\
\hline & Fischerinidae & Vertebralina striata & SB & 0 & 0 & 0 & 0 & 53 & 122 \\
\hline
\end{tabular}

The density of foraminifera was lowest at $P$. oceanica leaves on site mix (average $3183 \pm 671$ individuals $\mathrm{m}^{-2}$ surface area), with a significant difference between the two leaf sites (site mix and site PO). The highest density was found on P. crispa site PC1 (average $12,647 \pm 1017$ individuals $\mathrm{m}^{-2}$ surface area). Comparing the density among habitats revealed significantly higher values for $P$. crispa compared to $P$. oceanica shoots and leaves on site Mix ( $p=0.0198$ and $p<0.0001$, respectively; Figure 3A).

The number of taxa was lowest on the P. oceanica leaves at site mix (average 5.0 \pm 0.3 ) and highest on P. crispa phylloids at site PC1 (average $28.0 \pm 0.7$ ). Significant differences were found among P. oceanica shoot sites and all habitats (Figure 3B). The number of taxa found on $P$. crispa was significantly higher compared to $P$. oceanica leaves and shoots on both $P$. oceanica sites (all values for $p<0.0213$ ).

The lowest Shannon diversity index was found on P. oceanica shoots (average $1.2 \pm 0.1$ ) and highest on $P$. crispa phylloids (average $2.5 \pm 0.2$ ), both at site mix. Both P. oceanica sub-habitats differed significantly, with higher values for site PO (Figure 3C). Among all habitats, $P$. crispa showed significantly more diversity than P. oceanica leaves and shoots (all values for $p<0.0039$ ).

The evenness was similar across all comparisons. The lowest average value was found on $P$. oceanica shoots at site mix (average $0.7 \pm 0.06$ ), and the highest on $P$. oceanica leaves at site PO (average $0.9 \pm 0.01$ ). The pairwise comparison between $P$. crispa and P. oceanica shoots on site PO showed the only significant effect ( $p=0.0002$; Figure 3D).

The FORAM index was highest for the P. oceanica shoots, with a significantly higher value for site $\operatorname{mix}(8.6 \pm 1.0)$ and lowest for the leaves, with a significantly lower value for site mix $(2.8 \pm 0.8)$. The values for all $P$. crispa samples ranged between the two $P$. oceanica sub-habitats (Figure 3E).

The lifespan index (ILS) was highest in the P. oceanica shoot samples from site mix $(25.4 \pm 7.0)$ and lowest in the leaf samples from the same site $(7.9 \pm 4.0)$. The $P$. crispa community showed similar values compared to $P$. oceanica site $\mathrm{PO}$, while it ranged between both sub-habitats on site mix (Figure 3F).

The relative abundances of foraminiferal taxa sorted by test material show differences among the two P. oceanica sites in the higher abundance of the porcellaneous Hauerinidae (mainly Milionella spp. and Quinqueloculina spp.) at site PO. In contrast, the composition across $P$. crispa sites is more homogenous (Figure 4 ). The phylloids of $P$. crispa host more porcelaneous foraminifera than both P. oceanica sub-habitats on the same site (site mix), 
mainly driven by an unidentified Hauerinidae species (Table 2). On the other hand, while agglutinated species were scarce in the whole study, they were relatively more abundant on P. oceanica sub-habitats (mainly Trochammina inflata and Lepidodeuterammina ochracea, Figure 4). The leaves of P. oceanica on the site mix did not host any porcelaneous foraminifera. The two $P$. oceanica sub-habitats mainly differ in the higher abundance of Sejunctella sp. (Spirillinidae; average $913 \pm 196$ individuals $\mathrm{m}^{-2}$ surface area; Figure 4).

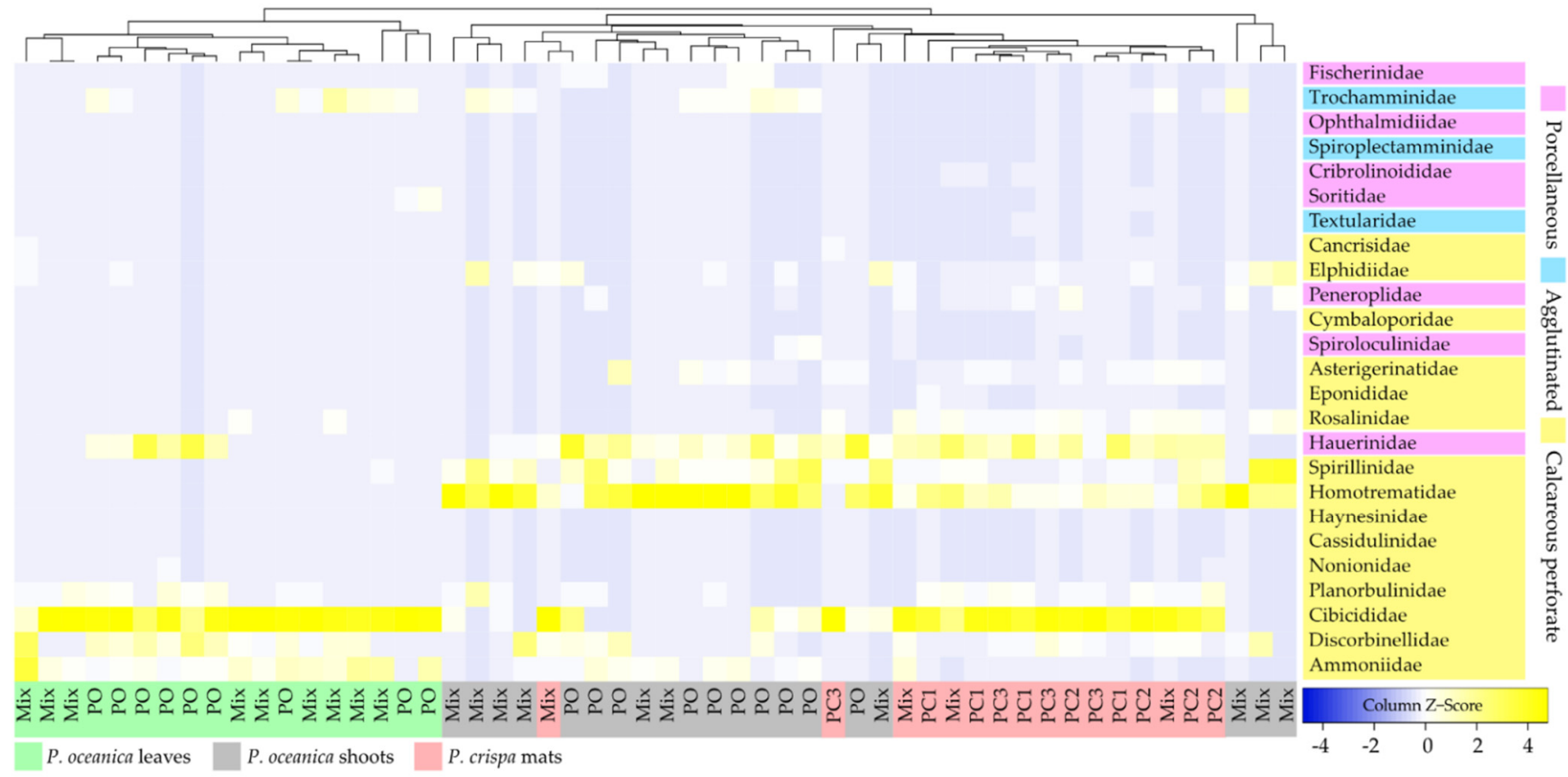

Figure 4. Hierarchical clustering (average linkage, Spearman ranked correlation) of family abundances among sites (individuals per $\mathrm{m}^{2}$ ) found in Phyllophora crispa (red) and Posidonia oceanica habitat sites (green = leaf; grey = shoot). Test types are indicated as purple (porcellaneaus), blue (agglutinated) and yellow (calcareous perforate). The Z-score indicates the distance to the mean, which is indicated as " 0 ".

Differences among sites for P. crispa were reflected in the lower abundances of Hauerinidae (unknown species) and Homotrematidae (i.e., M. miniacea) on site PC3 compared to all other sites (Figure 4). Among P. oceanica sites, differences were driven by the high abundance of an unknown Hauerinidae species on site PO (Figure 4).

\section{Discussion}

\subsection{Environmental Parameters inside P. crispa Mats}

The $\mathrm{pH}$ and oxygen concentrations inside the $P$. crispa mats differed from the environment inside $P$. oceanica meadows, mainly regarding the magnitude of their daily cycles (Figure 2). While the oxygen concentrations inside the P. crispa mat were similar to the bare rock reference habitat, the $\mathrm{pH}$ values showed more substantial fluctuations than the P. oceanica meadow. The lower oxygen concentrations inside the P. oceanica meadow were likely due to the measurements close to the rhizome layer, where more respiration occurred [61]. This effect also explains the lower $\mathrm{pH}$ values measured inside the P. oceanica meadow. A reason could be the spatial proximity of the photosynthetically active thalli of the red algae with the epiphytic respirating community, in contrast to the spatially more detached situation in the P. oceanica meadow. The resulting small-scale gradients of environmental parameters inside $P$. crispa mats were also recently described for water movement, temperature, and light conditions [10]. 


\subsection{Abundance and Diversity of Epiphytic Foraminifera in P. crispa Mats}

Overall, the foraminiferal assemblages represent a typical composition for carbonated shelf environments [61]. Our results showed that the abundance of foraminifera was higher in P. crispa mats than in both P. oceanica sub-habitats. A similar, but more pronounced trend was confirmed for the species richness (Figure 3). This observation is strengthened by the fact that previous studies found lower values for foraminiferal diversity on seagrass [62]. Additionally, the analysis of species incidences showed that our sampling efforts might even underestimate the total diversity of foraminiferal communities in P. crispa mats (see Appendix A Figure A2).

Interestingly, the leaf sites differed in density, while the shoot sites differed in species richness. This observation supports that $P$. oceanica sub-habitats provide different ecological traits (e.g., water movement, particle supply, light availability), especially for foraminiferal species. The high individual count on site PO leaves could have resulted from a recent reproduction event in that area, which usually occurs during summer [62]. The relative abundance of foraminiferal orders shows that the lack of porcelaneous taxa and differences in the composition of calcareous perforate taxa were the main drivers for the observed differences. Additionally, the relatively short-lived P. oceanica leaves favor small species (ecotype B, mainly L. lobatula) with high turnover rates compared to the long-lived shoots and P. crispa mats, where LFB (e.g., Peneroplis spp.) occur in persistent habitats [30]. This observation is confirmed by the higher lifespan index values (ILS) for P. oceanica shoots and P. crispa mats. Shannon indices support the at least comparably high foraminiferal diversity in P. crispa mats and higher consistency among sites in this habitat. While no statistical differences in the evenness were confirmed, the data scattering in P. oceanica samples shows high dispersion across replicates (Figure 3), pointing towards small-scale variations in the resilience of foraminiferal communities across P. oceanica meadows. Although there is no significant effect, we observe a trend to lower values on the southernmost site (site PC3, Figure 3) while, in contrast to P. oceanica, the sites within the north-western bay (bay of Campese), overall values are more similar. Our findings are consistent with previous studies on epiphytic foraminifera, where 55 living taxa were found on Cystoseira sp. (Phaeophyta) mats [25] and 62 taxa in shallow algae assemblages [24]. Adding to the results of Langer (1988) [38], who found lower diversities of foraminifera in green algae (Udotea peticolata) and brown algae (Ectocarpus sp.) compared to seagrass (P. oceanica), we confirm here that red algae mats of $P$. crispa have the potential to host even higher diversities than P. oceanica.

\subsection{Composition of Epiphytic Foraminifera Morphotypes in P. crispa Mats}

The test type comparison shows a similar trend to a more homogenous community across sites in P. crispa mats, while foraminiferal groups of different test types are more abundant on few P. oceanica samples (e.g., Trochaminidae, Hauerinidae, Discorbinellidae; Figure 4). The higher abundance of porcelaneous LBF taxa reflects the long-term stability of $P$. crispa mats (similar to P. oceanica shoots), accompanied with higher light regimes (similar to P. oceanica leaves) as species of porcelaneous LBF are often multichambered species, bearing photosymbionts [61,63]. Because of their calcified test, porcelaneous species are more sensitive to ocean acidification processes [64]. This is further supported by the low number of agglutinated, typically opportunistic species, favoring more unstable, physically controlled environments [65]. High abundances of agglutinated species also indicate carbonate undersaturation [66]. The low values (average $38 \pm 62$ individuals $\mathrm{m}^{-2}$ surface area) in this study suggest a relatively high nutrient availability and water mixture inside the P. crispa habitat. These traits are generally provided by P. crispa mats, where we found the highest numbers of LBF. However, these high numbers were mainly driven by Peneroplis pertusus, which was also abundant on $P$. oceanica shoots. The lack of porcelaneous foraminifera on both P. oceanica sub-habitats on site mix compared to site PO (Appendix A Table A1) indicates local factors (i.e., disturbances or pollution). Another explanation could be a lack of larval supply; however, the high amount of porcelaneous species in P. crispa mats on the same site (Appendix A Table A2) implicates local factors inside 
the $P$. oceanica meadow as the main drivers. This observation underlines the function of $P$. crispa mats as refuge habitat and potential mitigating mechanisms for environmental disturbances accompanied with the mats. A recent study suggests that diel $\mathrm{pH}$ fluctuations in $P$. oceanica meadows foster the resistance of epiphytic forams (Rosalina sp.) towards ocean acidification [67]. Our study found higher diel $\mathrm{pH}$ fluctuations within P. crispa mats (0.11 units) than in P. oceanica meadows (0.05 units, Figure 2$)$. This observation conforms with a higher abundance and diversity of Rosalina sp. in P. crispa habitats (6 species, average $27 \pm 53$ individuals $\mathrm{m}^{-2}$ surface area) compared to $P$. oceanica habitats $(1$ species, average $3 \pm 22$ individuals $\mathrm{m}^{-2}$ surface area leaves and average $0 \pm 4$ individuals $\mathrm{m}^{-2}$ surface area shoots). This observation supports the hypothesis that P. crispa mats could also foster the resistance of epiphytic forams against acidification scenarios as observed in P. oceanica [67]. These higher $\mathrm{pH}$ regimes could result from an accumulation of organic particles and thus higher net respiration in combination with elevated water holding capacities of $P$. crispa mats [10] and lower rates of photosynthesis, as shown by lower oxygen concentrations inside the algae mats (Figure 2B).

While P. crispa was dominated by a combination of type B (L. lobatula) and type $\mathrm{A}^{*}$ (M. miniacea, and unknown Hauerinidae), the leaves and shoots of $P$. oceanica were dominated by one very abundant type $\left(\mathrm{B}-\right.$ L. lobatula and $\mathrm{A}^{*}-M$. miniacea, respectively, Table 2). This difference indicates that P. crispa mats offer various traits for long-lived, encrusting species $\left(\mathrm{A}^{*}\right)$ and short-lived and temporary motile species (B), but on the other hand, offer suitable conditions for species from both $P$. oceanica sub-habitats. The high abundance and diversity of porcellaneous LBF species confirm the function of $P$. crispa mats as persistent habitats.

Notably, LBF species were overall scarce in this study and absent in some samples across habitats, resulting in high standard deviations (Table 2, Appendix A Tables A1 and A2). For example, S. orbiculus was only found in two leaf samples, with relatively high abundances. A reason for this aggregation of LBF species in some samples could be local asexual reproduction, previously described for LBF species [68]. However, while LBFs were present in 11 P. crispa samples across all sites, they were found in 2 samples of $P$. oceanica leaves from site $\mathrm{PO}$, and 8 samples of $P$. oceanica shoots from both sites.

\section{Conclusions}

We conclude that the community of epiphytic foraminifera $>300 \mu \mathrm{m}$ is of higher diversity in P. crispa mats (Appendix A Figure A2) and is more homogeneously distributed across sites and replicates than $P$. oceanica sub-habitats. The fact that $P$. crispa mats are a suitable habitat for many foraminiferal species of both $P$. oceanica sub-habitats leads to the hypothesis that $P$. crispa mats may act as refuge habitats harboring biodiversity in times of loss and degradation of neighboring diversity hotspots. It underlines the relevance of this habitat in the Mediterranean Sea and justifies further assessments of P. crispa mat distribution along the Mediterranean coastline to confirm our results on a regional scale. We suggest further investigating the supraregional distribution and diversity of this vital rhodophyte habitat across the Mediterranean coastline to prove further its role as a vital habitat of high biodiversity. The recently adopted EU Biodiversity strategy for 2030 aims to protect and restore habitats of significant biodiversity to mitigate effects of e.g., regional human impact and climate change in terms of biodiversity loss. Our results in line with previous studies on $P$. crispa mats [17-22], as well as the successful implementation of a marine protected area covering "Zernov's Phyllophora field" in the Black Sea [23] suggest that this habitat hosts considerably high diversity of invertebrate taxa and should thus be considered in future conservation efforts. 
Author Contributions: Conceptualization, F.I.R., B.M. and C.W.; methodology, F.I.R. and B.M; validation, F.I.R., B.M. and C.W.; formal analysis, F.I.R.; investigation, F.I.R. and B.M.; resources, C.W.; data curation, F.I.R.; writing-original draft preparation, F.I.R.; writing—review and editing, F.I.R., B.M. and C.W.; visualization, F.I.R.; supervision, C.W.; project administration, C.W.; funding acquisition, C.W. All authors have read and agreed to the published version of the manuscript.

Funding: This study was supported by baseline funding of the Marine Ecology Department, University of Bremen (Bremen, Germany), and the "Institut für Marine Biologie" (IfMB, Karlsruhe, Germany).

Institutional Review Board Statement: Not applicable.

Informed Consent Statement: Not applicable.

Data Availability Statement: The Dataset, including a complete species list, supporting the conclusions of this study is available in the "PANGAEA" online repository: https:/ / doi.pangaea.de/10.159 4/PANGAEA.936751 (accessed on 18 December 2021).

Acknowledgments: The authors would like to thank Jenny Tuček and Mischa Schwarzmeier (IfMB), as well as Reiner and Regina Krumbach (Campese Diving Center), for logistical support throughout our study. We are also thankful to Susann Roßbach for providing helpful feedback on the manuscript and Anette Reh for support in sampling activities.

Conflicts of Interest: The authors declare no conflict of interest.

\section{Appendix A}

Formula (A1): Calculation of the Shannon index $\left(H^{\prime}\right)$, using the proportion of each individual taxon $p_{i}=n / N$, where $n=$ the number of individuals of a given taxon and $N=$ the total number of individuals per sample:

$$
H^{\prime}=\sum_{i=0}^{R} p_{i} \ln p_{i}
$$

Formula (A2): Calculation of the Pielou index $(J)$, using the Shannon index $\left(H^{\prime}\right)$, and the total number of taxa $(S)$ :

$$
J=H^{\prime} / \ln S
$$

Table A1. Abundance of LBF species in P. oceanica sites and sub-habitats. Numbers are average abundance per $\mathrm{m}^{2}$ substrate $(\mathrm{AVG}) \pm$ standard deviation (STDEV).

\begin{tabular}{ccccccccc}
\hline \multirow{2}{*}{ Species } & \multicolumn{2}{c}{ Leaves Site Mix } & \multicolumn{2}{c}{ Leaves Site PO } & Shoots Site Mix & \multicolumn{2}{c}{ Shoots Site PO } \\
\cline { 2 - 9 } & AVG & STDEV & AVG & STDEV & AVG & STDEV & AVG & STDEV \\
\hline Vertebralina striata & 0 & 0 & 0 & 0 & 0 & 0 & 105 & 151 \\
Peneroplis pertusus & 0 & 0 & 0 & 0 & 92 & 177 & 41 & 82 \\
Sorites orbiculus & 0 & 0 & 73 & 160 & 0 & 0 & 0 & 0 \\
\hline
\end{tabular}

Table A2. Abundance of LBF species in P. crispa sites. Numbers are average abundance per $\mathrm{m}^{2}$ substrate $(\mathrm{AVG}) \pm$ standard deviation (STDEV).

\begin{tabular}{ccccccccc}
\hline \multirow{2}{*}{ Species } & \multicolumn{2}{c}{ Site PC1 } & \multicolumn{2}{c}{ Site PC2 } & \multicolumn{2}{c}{ Site PC3 } & \multicolumn{2}{c}{ Site Mix } \\
\cline { 2 - 8 } & AVG & STDEV & AVG & STDEV & AVG & STDEV & AVG & STDEV \\
\hline Peneroplis pertusus & 92 & 132 & 272 & 272 & 49 & 49 & 200 & 324 \\
Peneroplis planatus & 0 & 0 & 17 & 30 & 31 & 54 & 20 & 34 \\
Sorites orbiculus & 0 & 0 & 41 & 72 & 0 & 0 & 10 & 17 \\
\hline
\end{tabular}




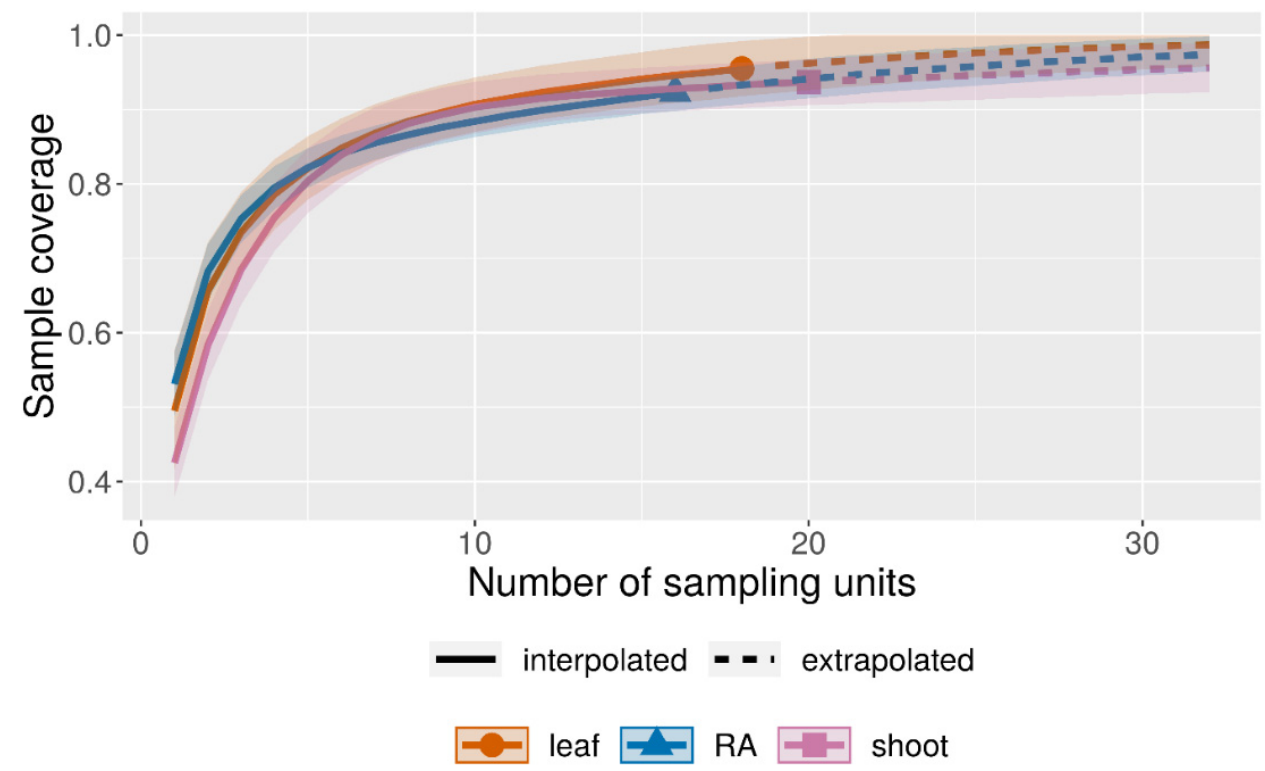

Figure A1. Sample completeness based on species incidence data according to Chao et al. [53]. Number of bootstraps used: 500; level of confidence: 0.95 . Habitats with sample coverage (C. hat): "leaf" = Posidonia oceanica leaves (0.95), "RA" = Phyllophora crispa mats (0.92), "shoot" = Posidonia oceanica shoots (0.94).

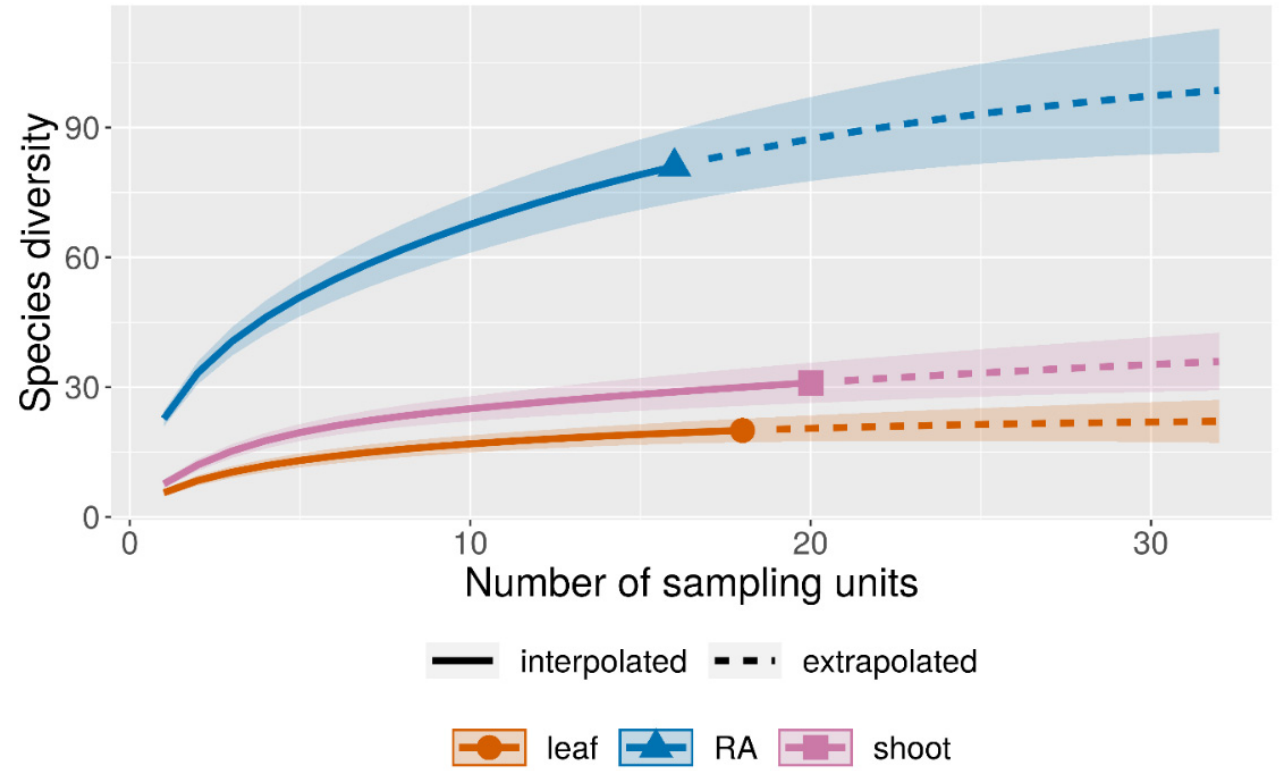

Figure A2. Species diversity extrapolated on number of sampling units, following the method of Chao et al. [53]. Number of bootstraps used: 500; level of confidence: 0.95. Habitats: "leaf" = Posidonia oceanica leaves, "RA" = Phyllophora crispa mats, "shoot" = Posidonia oceanica shoots.

\section{References}

1. Coll, M.; Piroddi, C.; Steenbeek, J.; Kaschner, K.; Ben Rais Lasram, F.; Aguzzi, J.; Ballesteros, E.; Bianchi, C.N.; Corbera, J.; Dailianis, T.; et al. The Biodiversity of the Mediterranean Sea: Estimates, Patterns, and Threats. PLoS ONE 2010, 5, e11842. [CrossRef] [PubMed]

2. Defant, A. Physical Oceanography; Pergamon: New York, NY, USA, 1961; Volume 1.

3. Medail, F.; Quezel, P. Biodiversity Hotspots in the Mediterranean Basin: Setting Global Conservation Priorities. Conserv. Biol. 1999, 13, 1510-1513. [CrossRef]

4. Bianchi, C.N.; Morri, C. Marine Biodiversity of the Mediterranean Sea: Situation, Problems and Prospects for Future. Mar. Pollut. Bull. 2016, 40, 367-376. [CrossRef] 
5. Boudouresque, C.F.; Bernard, G.; Bonhomme, P.; Charbonnel, E.; Diviacco, G.; Meinesz, A.; Pergent, G.; Pergent-Martini, C.; Ruitton, S.; Tunesi, L. Préservation et Conservation des Herbiers à Posidonia Oceanica; Ramoge: Tunis, Tunesia, 2006; ISBN 2905540303.

6. Mazzella, L.; Buia, M.C.; Gambi, M.C.; Lorenti, M.; Russo, G.F.; Scipione, M.B.; Zupo, V. Plant-animal trophic relationships in the Posidonia oceanica ecosystem of the Mediterranean Sea: A review. Plant-Anim. Interact. Mar. Benthos 1992, 46, $165-187$.

7. Ballesteros, E. Mediterranean coralligenous assemblages: A synthesis of present knowledge. In Oceanography and Marine Biology: An Annual Review; Gibson, R.N., Atkinson, R.J.A., Gordon, J.D.M., Eds.; Taylor \& Francis: Abingdon, UK, 2006; pp. $123-195$.

8. Cocito, S. Bioconstruction and biodiversity: Their mutual influence. Sci. Mar. 2004, 68, 137-144. [CrossRef]

9. Ingrosso, G.; Abbiati, M.; Badalamenti, F.; Bavestrello, G.; Belmonte, G.; Cannas, R.; Benedetti-Cecchi, L.; Bertolino, M.; Bevilacqua, S.; Bianchi, C.N.; et al. Mediterranean Bioconstructions Along the Italian Coast, 1st ed.; Elsevier Ltd.: Amsterdam, The Netherlands, 2018; Volume 79, ISBN 9780128151013.

10. Schmidt, N.; El-khaled, Y.C.; Rossbach, F.I.; Wild, C. Fleshy red algae mats influence their environment in the Mediterranean Sea. Front. Mar. Sci. 2021, 8, 1626. [CrossRef]

11. Lepoint, G.; Balancier, B.; Gobert, S. Seasonal and depth-related biodiversity of leaf epiphytic Cheilostome Bryozoa in a Mediterranean Posidonia oceanica meadow. Cah. Biol. Mar. 2014, 55, 57-67.

12. Stachowicz, J.J. The Structure of Ecological Communities. Bioscience 2001, 51, 235-246. [CrossRef]

13. Stachowicz, J.J.; Hay, M.E. Facultative mutualism between an herbivorous crab and a coralline alga: Advantages of eating noxious seaweeds. Oecologia 1996, 105, 377-387. [CrossRef]

14. Duffy, J.E. Amphipods on seaweeds: Partners or pests? Oecologia 1990, 83, 267-276. [CrossRef] [PubMed]

15. Tomas, F.; Turon, X. Seasonal and small-scale spatial variability of herbivory pressure on the temperate seagrass Posidonia oceanica. Mar. Ecol. Prog. Ser. 2005, 301, 95-107. [CrossRef]

16. Piazzi, L.; Balata, D.; Ceccherelli, G. Epiphyte assemblages of the Mediterranean seagrass Posidonia oceanica: An overview. Mar. Ecol. 2016, 37, 3-41. [CrossRef]

17. Navone, A.; Bianchi, C.N.; Orru, P.; Ulzega, A. Saggio di cartografia geomorfologica e bionomica nel parco marino di TavolaraCapo Coda di Cavallo (Sardegna nord-orientale). Oebalia 1992, XVII, 469-478.

18. Bianchi, C.N.; Morri, C.; Navone, A. I popolamenti delle scogliere rocciose sommerse dell'Area Marina Protetta di Tavolara Punta Coda Cavallo (Sardegna nord-orientale). Sci. Rep. Port-Cros Natl. Park 2010, 24, 39-85.

19. Casoli, E.; Bonifazi, A.; Giandomanico, A.; Gravina, M.F.; Russo, G.F.; Sandulli, R.; Donnarumma, L. Comparative Analysis of Mollusc Assemblages from Different Hard Bottom Habitats in the Central Tyrrhenian Sea. Diversity 2019, 11, 74. [CrossRef]

20. Bonifazi, A.; Ventura, D.; Gravina, M.F.; Lasinio, G.J.; Belluscio, A.; Ardizzone, G.D. Unusual algal turfs associated with the rhodophyta Phyllophora crispa: Benthic assemblages along a depth gradient in the Central Mediterranean Sea. Estuar. Coast. Shelf Sci. 2017, 185, 77-93. [CrossRef]

21. Casoli, E.; Bonifazi, A.; Ardizzone, G.; Gravina, M.F. How algae influence sessile marine organisms: The tube worms case of study. Estuar. Coast. Shelf Sci. 2016, 178, 12-20. [CrossRef]

22. Rossbach, F.I.; Casoli, E.; Beck, M.; Wild, C. Mediterranean Red Macro Algae Mats as Habitat for High Abundances of Serpulid Polychaetes. Diversity 2021, 13, 265. [CrossRef]

23. Kostylev, E.F.; Tkachenko, F.P.; Tretiak, I.P. Establishment of Zernov's Phyllophora field marine reserve: Protection and restoration of a unique ecosystem. Ocean Coast. Manag. 2010, 53, 203-208. [CrossRef]

24. Koukousioura, O.; Dimiza, M.D.; Triantaphyllou, M.V.; Hallock, P. Living benthic foraminifera as an environmental proxy in coastal ecosystems: A case study from the Aegean Sea (Greece, NE Mediterranean). J. Mar. Syst. 2011, 88, 489-501. [CrossRef]

25. Sciuto, F.; Sanfilippo, R.; Alongi, G.; Catra, M.; Serio, D.; Bejaoui, S.; Leonardi, R.; Viola, A.; Rosso, A. First data on ostracods and foraminifera living in Cystoseira communities in western Ionian Sea (southern Italy, Mediterranean Sea). Mediterr. Mar. Sci. 2017, $18,64-76$.

26. Donnarumma, L.; Sandulli, R.; Appolloni, L.; Russo, G.F. Assessing molluscs functional diversity within different coastal habitats of Mediterranean marine protected areas. Ecol. Quest. 2018, 29, 35-51. [CrossRef]

27. Buonocore, E.; Donnarumma, L.; Appolloni, L.; Miccio, A.; Russo, G.F.; Franzese, P.P. Marine natural capital and ecosystem services: An environmental accounting model. Ecol. Modell. 2020, 424, 109029. [CrossRef]

28. Holzmann, M.; Habura, A.; Giles, H.; Bowser, S.S.; Pawlowski, J. Freshwater foraminiferans revealed by analysis of environmental DNA samples. J. Eukaryot. Microbiol. 2003, 50, 135-139. [CrossRef]

29. Siemensma, F.; Apothéloz-Perret-Gentil, L.; Holzmann, M.; Clauss, S.; Völcker, E.; Pawlowski, J. Taxonomic revision of freshwater foraminifera with the description of two new agglutinated species and genera. Eur. J. Protistol. 2017, 60, 28-44. [CrossRef]

30. Alve, E. Colonization of new habitats by benthic foraminifera: A review. Earth Sci. Rev. 1999, 46, 167-185. [CrossRef]

31. Carnahan, E.A.; Hoare, A.M.; Hallock, P.; Lidz, B.H.; Reich, C.D. Foraminiferal assemblages in Biscayne Bay, Florida, USA: Responses to urban and agricultural influence in a subtropical estuary. Mar. Pollut. Bull. 2009, 59, 221-233. [CrossRef]

32. Milker, Y.; Schmiedl, G. A taxonomic guide to modern benthic shelf foraminifera of the western Mediterranean sea. Palaeontol. Electron. 2012, 15, 1-134. [CrossRef]

33. Casieri, S.; Frezza, V.; Mancini, S.; Carboni, M.G. Living sessile epiphytic foraminifera from Posidonia oceanica meadows of Ischia and Ponza Islands. Giornate Paleontol. 1993, 8, 9-13.

34. Semeniuk, T.A. Spatial variability in epiphytic foraminifera from micro-to regional scale. J. Foraminifer. Res. 2000, 30, 99-109. [CrossRef] 
35. Mateu-Vicens, G.; Khokhlova, A.; Sebastian-Pastor, T. Epiphytic foraminiferal indices as bioindicators in Mediterranean seagrass meadows. J. Foraminifer. Res. 2014, 44, 325-339. [CrossRef]

36. Cimerman, F.; Langer, M.R. Mediterranean Foraminifera; Slovenska Akademija Znanosti in Umetnosti: Ljubljana, Slovenia, 1991; ISBN 9789401054805.

37. Langer, M.R. Epiphytic foraminifera. Mar. Micropaleontol. 1993, 20, 235-265. [CrossRef]

38. Langer, M. Recent epiphytic foraminifera from Vulcano (Mediterranean Sea). Rev. Paléobiologie 1988, 2, 827-832.

39. Mateu-Vicens, G.; Box, A.; Deudero, S.; Rodríguez, B. Comparative analysis of epiphytic foraminifera in sediments colonized by seagrass Posidonia oceanica and invasive macroalgae Caulerpa spp. J. Foraminifer. Res. 2010, 40, 134-147. [CrossRef]

40. Lee, J.J. Algal symbiosis in larger foraminifera. Symbiosis 2006, 42, 63-75.

41. Ross, C.A. Biology and Ecology of Marginopora vertebralis (Foraminiferida), Great Barrier Reef. J. Protozool. 1972, 19, 181-193. [CrossRef]

42. Leutenegger, S. Symbiosis in benthic foraminifera: Specificity and host adaptations. J. Foraminifer. Res. 1984, 14, 16-35. [CrossRef]

43. Langer, M.R. Assessing the contribution of foraminiferan protists to global ocean carbonate production. J. Eukaryot. Microbiol. 2008, 55, 163-169. [CrossRef]

44. Uthicke, S.; Thompson, A.; Schaffelke, B. Effectiveness of benthic foraminiferal and coral assemblages as water quality indicators on inshore reefs of the Great Barrier Reef, Australia. Coral Reefs 2010, 29, 209-225. [CrossRef]

45. Uthicke, S.; Nobes, K. Benthic Foraminifera as ecological indicators for water quality on the Great Barrier Reef. Estuar. Coast. Shelf Sci. 2008, 78, 763-773. [CrossRef]

46. Hallock, P.; Lidz, B.H.; Cockey-Burkhard, E.M.; Donnelly, K.B. Foraminifera as bioindicators in coral reef assessment and monitoring: The foram index. Environ. Monit. Assess. 2003, 81, 221-238. [CrossRef]

47. Pawlowski, J.; Esling, P.; Lejzerowicz, F.; Cedhagen, T.; Wilding, T.A. Environmental monitoring through protist next-generation sequencing metabarcoding: Assessing the impact of fish farming on benthic foraminifera communities. Mol. Ecol. Resour. 2014, 14, 1129-1140. [CrossRef]

48. Prazeres, M.; Roberts, T.E.; Pandolfi, J.M. Variation in sensitivity of large benthic Foraminifera to the combined effects of ocean warming and local impacts. Sci. Rep. 2017, 7, 45227. [CrossRef]

49. Prazeres, M.; Ainsworth, T.; Roberts, T.E.; Pandolfi, J.M.; Leggat, W. Symbiosis and microbiome flexibility in calcifying benthic foraminifera of the great Barrier Reef. Microbiome 2017, 5, 1-11. [CrossRef]

50. Schlitzer, R. Ocean Data View 2016. Available online: http:/ / odv.awi.de (accessed on 21 December 2021).

51. Kikuchi, T.; Pérès, J.M. Animal communities in seagrass beds: A review. In Seagrass Ecosystems: A Scientific Perspective; McRoy, C.P., Helfferich, C., Eds.; Marcel Dekker: New York, NY, USA, 1967; pp. 147-193.

52. Kikuchi, T. Handbook of Seagrass Biology: An Ecosystem Perspective; Phillips, R.C., McRoy, C.P., Eds.; Garland STPM Press: New York, NY, USA, 1980.

53. Chao, A.; Chiu, C.-H. Nonparametric Estimation and Comparison of Species Richness. eLS 2016, 1-11. [CrossRef]

54. Murray, J.W. British nearshore foraminiferids. In Synopses of the British Fauna (New Series); Kermack, D.M., Barnes, R.S.K., Eds.; Academic Press: London, UK, 1979; p. 68. ISBN 0125118503.

55. Holbourn, A.; Henderson, A.S.; Macleod, N. Atlas of Benthic Foraminifera; Wiley-Blackwell: Hoboken, NJ, USA, 2013; ISBN 978-1118-38980-5.

56. Shannon, C.E. A mathematical theory of communication. Bell Syst. Tech. J. 1948, 27, 379-423. [CrossRef]

57. Pielou, E.C. The measurement of diversity in different types of biological collections. J. Theor. Biol. 1966, 13, 131-144. [CrossRef]

58. McArdle, B.H.; Anderson, M.J. Fitting multivariate models to community data: A comment on distance-based redundancy analysis. Ecology 2001, 82, 290-297. [CrossRef]

59. Babicki, S.; Arndt, D.; Marcu, A.; Liang, Y.; Grant, J.R.; Maciejewski, A.; Wishart, D.S. Heatmapper: Web-enabled heat mapping for all. Nucleic Acids Res. 2016, 44, W147-W153. [CrossRef]

60. R Core Team. R: A Language and Environment for Statistical Computing; R Foundation for Statistical Computing: Vienna, Austria, 2021.

61. Murray, J.W. Ecology and Applications of Benthic Foraminifera; Cambridge University Press: Cambridge, UK, 2006.

62. Novak, R. Spatial and seasonal distribution of the meiofauna in the seagrass Posidonia oceanica. Neth. J. Sea Res. 1982, 16, 380-388. [CrossRef]

63. Lee, J.J.; Anderson, O.R. Symbiosis in foraminifera. In Biology of Foraminifera; Academic Press: London, UK, 1991; pp. 157-220.

64. Glas, M.S.; Fabricius, K.E.; de Beer, D.; Uthicke, S. The $\mathrm{O}_{2}, \mathrm{pH}$ and $\mathrm{Ca}^{2+}$ Microenvironment of Benthic Foraminifera in a High $\mathrm{CO}_{2}$ World. PLoS ONE 2012, 7, e50010. [CrossRef] [PubMed]

65. Harloff, J.; Mackensen, A. Recent benthic foraminiferal associations and ecology of the Scotia Sea and Argentine Basin. Mar. Micropaleontol. 1997, 31, 1-29. [CrossRef]

66. Murray, J.W.; Alve, E. The distribution of agglutinated foraminifera in NW European seas: Baseline data for the interpretation of fossil assemblages. Palaeontol. Electron. 2011, 14, 1-41.

67. Ramajo, L.; Lagos, N.A.; Duarte, C.M. Seagrass Posidonia oceanica diel pH fluctuations reduce the mortality of epiphytic forams under experimental ocean acidification. Mar. Pollut. Bull. 2019, 146, 247-254. [CrossRef] [PubMed]

68. Boudagher-Fadel, K.M. Biology and Evolutionary History of Larger Benthic Foraminifera. In Evolution and Geological Significance of Larger Benthic Foraminifera; UCL Press: London, UK, 2018; pp. 1-44, ISBN 9781911576938. 